\title{
PENGARUH LITERASI KEUANGAN TERHADAP PERENCANAAN KEUANGAN KELUARGA DI KOTA MATARAM
}

\author{
Dahlia Bonang \\ UIN Mataram, \\ dahlia_db@uinmataram.ac.id
}

\begin{abstract}
Financial literacy and financial planning for every Indonesian family are important. It is because the family is one of the pillars of the economy where the financial health of the family will have an influence on the overall financial health of the country. If based on the province, NTB's financial literacy index is 17 th in 34 provinces in Indonesia at $21.45 \%$. This figure indicates that there is still a low level of understanding, knowledge and access of people in NTB to institutions, financial products, and services. Therefore financial education and supporting infrastructure development must be carried out continuously so that public financial literacy can reach well literate. This research is a field research. Data collection methods used are observation, interviews and questionnaires. This study used a sample of 100 people. The sampling technique is by random sampling due to research efficiency.

The output of the $F$ test shows that the calculated $F$ value is 4.516 with a significance level of 0.036 . The significance level is $0.036<0.05$, so it can be interpreted that there is an influence of financial literacy variable $(X)$ on the family financial planning variable $(Y)$. Similarly, it is proven by testing the second hypothesis with the $T$ test. The output of the $T$ test can be seen that the value of $t$ count is 2.125 . Then after $t$ count compared to $t$ table which has a value of 1,980 . With the value of $t$ count $2.125>t$ table 1.980 it can be concluded that $\mathrm{Ho}$ is accepted which means that "there is an influence of financial literacy $(X)$ on family financial planning $(Y)$.
\end{abstract}

Keywords: Financial Literacy, Financial Planning 


\begin{abstract}
Abstrak
Literasi keuangan dan perencanaan keuangan bagi setiap keluarga indonesia merupakan hal yang penting. Hal ini disebabkan karena keluarga merupakan salah satu pilar perekonomian dimana kesehatan keuangan keluraga akan memberikan pengaruh terhadap kesehatan keuangan negara secara keseluruhan. Jika bedasarkan provinsi, indeks literasi keuangan NTB berada di urutan 17 dari 34 provinsi di Indonesia yaitu sebesar 21,45 \%. Angka ini menandakan bahwa masih rendahnya pemahaman, pengetahuan dan akses masyarakat di NTB terhadap Lembaga, produk, dan jasa keuangan. Oleh sebab itu hendaknya edukasi keuangan dan pembangunan infrasturktur pendukung dilakukan terus menerus sehingga literasi keuangan masyarakat bisa mencapai well literate. Penelitian ini merupakan penelitian lapangan. Metode pengumpulan data yang digunakan adalah observasi, wawancara dan angket. Penelitian ini menggunakan sampel 100 orang. Teknik pengambilan sampel dengan cara random sampling dikarenakan untuk efesiensi penelitian.

Hasil output dari uji F diketahui bahwa nilai $F$ hitung sebesar 4,516 dengan tingkat signifikansi sebesar 0,036. Tingkat signifikansi 0,036<0,05 maka dapat diinterpretasikan bahwa ada pengaruh variabel literasi keuangan $(\mathrm{X})$ terhadap variabel perencanaan keuangan keluarga $(\mathrm{Y})$. Demikian pula dibuktikan dengan pengujian hipotesis yang kedua dengan uji T. Hasil output dari uji T dapat diketahui bahwa nilai t hitung sebesar 2,125. Kemudian setelah $\mathrm{t}$ hitung dibandingkan dengan $\mathrm{t}$ tabel yang memiliki nilai sebesar 1,980. Dengan nilai t hitung 2,125 > t tabel 1,980 dapat disimpulkan bahwa Ho diterima yang berarti bahwa "ada pengaruh literasi keuangan (X) terhadap perencanaan keuangan keluarga $(Y)$.
\end{abstract}

Kata kunci: Literasi Keuangan, Perencanaan Keuangan 


\section{PENDAHULUAN}

Pada saat ini dunia tidak hanya menghadapi krisis global melainkan krisis keuangan pun sedang di hadapinya. Beberapa tahun belakangan ini, di berbagai belahan dunia isu mengenai literasi keuangan (financial literacy) tengah hangat di perbincangkan. Hal tersebut tidak lepas dari faktor penduduk yang semakin hari semakin bertambah serta perkembangan pasar keuangan yang semakin pesat menjadi kekhawatiran tersendiri bagi berbagai pihak, khususnya di Indonesia. Miniminya pengetahuan keuangan diakui sebagai salah satu faktor yang berkontribusi terhadap keputusan keuangan yang minim informasi sehingga dapat menimbulkan dampak negative (indah: 2017)

Secara umum, literasi keuangan digunakan sebagai alat ukur untuk mengetahui seberapa banyak masyarakat yang tidak memiliki pengetahuan mengenai lembaga jasa keuangan beserta produk dan jasa keuangan yang tersedia. Masyarakat perlu diberikan pengetahuan yang mencukupi mengenai berbagai hal yang terkait dengan masalah keuangan. Dengan bertambahnya tingkat literasi keuangan masyarakat maka diharapkan masyarakat dapat membuat keputusan keuangan dengan lebih baik sehingga perencanaan keuangan keluarga menjadi lebih optimal. Selain itu, diharapkan dapat mendorong minat masyarakat untuk berinvestasi lebih tinggi demi tercapainya pertumbuhan ekonomi nasional. Selain itu literasi keuangan memberikan manfaat bagi yang besar bagi sektor jasa keuangan. Lembaga keuangan dan masyarakat saling membutuhkan satu sama lain sehingga semakin tinggi tingkat literasi keuangan masyarakat, maka semakin banyak masyarakat yang akan memanfaatkan produk dan/atau layanan jasa keuangan.

Aktivitas perencanaan meliputi kegiatan untuk merencanakan alokasi pendapatan yang diperoleh akan digunakan untuk apa saja. Pengelolaan merupakan kegiatan untuk mengatur/mengelola keuangan secara efisien sedangkan pengendalian merupakan kegiatan untuk mengevaluasi apakah pengelolaan keuangan sudah sesuai dengan yang direncanakan/dianggarkan. keputusan keuangan yang diambil oleh seorang individu meliputi berapa jumlah uang yang harus dikonsumsi tiap periode, apakah ada kelebihan dan bagaimana kelebihan tersebut diinvestasikan serta bagaimana mendanai investasi dan konsumsi. individu yang memiliki kemampuan untuk membuat keputusan yang benar tentang keuangan tidak akan memiliki masalah keuangan dimasa depan dan menunjukkan perilaku keuangan yang sehat serta mampu menentukan prioritas kebutuhan bukan keinginan.

Data dari Otoritas Jasa Keuangan pada tahun 2013 menunjukkan bahwa 51\% keuangan keluarga Indonesia ditentukan oleh perempuan. OJK menyatakan bahwa tingkat pemahaman keuangan perempuan Indonesia masih berada pada angka 
18,84\% sedangkan pada pria mencapai 24,87\%. Namun pada tahun 2016 tingkat literasi pada perempuan mengalami peningkatan yakni $25 \%$ dan tingkat literasi pria sebanyak $33 \%$. Kurangnya pemahaman atas produk atau instrument keuangan ini cenderung disebabkan rendahnya literasi keuangan perempuan secara umum terhadap instrument investasi lainnya terutama yang tergolong baru seperti reksadana, obligasi, unit link, dsb (www.ojk.go.id).

Indeks literasi keuangan masyarakat Indonesia pada tahun 2016 mengalami peningkatan sebesar 29,66\% dibandingkan pada tahun 2013 sebesar 21,84\%. Jika bedasarkan provinsi, indeks literasi keuangan NTB berada di urutan 17 dari 34 provinsi di Indonesia yaitu sebesar 21,45\%. Angka ini menandakan bahwa masih rendahnya pemahaman, pengetahuan dan akses masyarakat di NTB terhadap Lembaga, produk, dan jasa keuangan sehingga perlu giat untuk melakukan edukasi keuangan dan pembangunan infrasturktur pendukung (Survei nasional literasi dan inklusi keuangan 2016).

Kajian mengenai literasi keuangan dan perencanaan keuangan sangat penting khususnya di Kota mataram disebabkan karena indeks literasi keuangan masyarakat di NTB masih rendah.

\section{LANDASAN TEORI}

\section{Literasi Keuangan}

Literasi keuangan menurut buku pedoman strategi nasional literasi keuangan Indonesia adalah rangkaian proses atau aktivitas untuk meningkatkan pengetahuan (knowledge), keyakinan (confidence), dan ketrampilan (skill) konsumen dan masyarakat luas sehingga mereka mampu mengelola keuangan yang lebih baik (Otoritas Jasa Keuangan, Literasi, edukasi, dan Inklusi Keuangan (Jakarta: Direktorat Literasi dan Edukasi, 2014: 4).

\section{a. Tujuan Literasi Keuangan}

Literasi Keuangan memiliki tujuan jangka panjang bagi seluruh golongan masyarakat, yaitu:

a) Meningkatkan literasi seseorang yang sebelumnya less literate atau not literate menjadi well literate

b) Meningkatkan jumlah pengguna produk dan layanan jasa keuangan.

c) Agar masyarakat luas dapat menentukan produk dan layanan jasa keuangan yang sesuai dengan kebutuhan. 
d) Masyarakat memiliki pemahaman yang benar tentang manfaat dan risiko

e) Masyarakat mengetahui hak dan kewajiban serta meyakini bahwa produk dan layanan jasa keuangan yang dipilih dapat meningkatkan kesejahteraan masyarakat.

b. Manfaat Literasi Keuangan

Bagi masyarakat, Literasi Keuangan memberikan manfaat yang besar, seperti:

a) Mampu memilih dan memanfaatkan produk dan layanan jasa keuangan yang sesuai kebutuhan; memiliki kemampuan dalam melakukan perencanaan keuangan dengan lebih baik;

b) Terhindar dari aktivitas investasi pada instrumen keuangan yang tidak jelas

c) Mendapatkan pemahaman mengenai manfaat dan risiko produk dan layanan jasa keuangan.

d) Literasi Keuangan juga memberikan manfaat yang besar bagi sektor jasa keuangan.

\section{c. Urgensi Edukasi Literasi Keuangan}

Pelaksanaan Edukasi dalam rangka meningkatkan keuangan masyarakat sangat diperlukan karena berdasarkan survei yang dilakukan oleh OJK pada 2013, bahwa tingkat literasi keuangan penduduk Indonesia dibagi menjadi empat bagian, yakni:

1. Well literate $(21,84 \%)$, yakni memiliki pengetahuan dan keyakinan tentang lembaga jasa keuangan serta produk jasa keuangan, termasuk fitur, manfaat dan risiko, hak dan kewajiban terkait produk dan jasa keuangan, serta memiliki keterampilan dalam menggunakan produk dan jasa keuangan.

2. Sufficient literate (75,69\%), memiliki pengetahuan dan keyakinan tentang lembaga jasa keuangan serta produk dan jasa keuangan, termasuk fitur, manfaat dan risiko, hak dan kewajiban terkait produk dan jasa keuangan

3. Less literate (2,06\%), hanya memiliki pengetahuan tentang lembaga jasa keuangan, produk dan jasa keuangan.

4. Not literate $(0,41 \%)$, tidak memiliki pengetahuan dan keyakinan terhadap lembaga jasa keuangan serta produk dan jasa keuangan, serta tidak memiliki keterampilan dalam menggunakan produk dan jasa keuangan. 


\section{Perencanaan Keuangan Keluarga}

\section{a. Definisi Perencanaan}

Perencanaan adalah pemilihan sekumpulan kegiatan dan pemutusan selanjutnya apa yang harus dilakukan, kapan, bagaimana,dan oleh siapa. Perencanaan yang baik dapat dicapai dengan mempertimbangkan kondisi di waktu yang akan datang dalam mana perencanaan yang diputuskan akan dilaksanakan, serta periode sekarang pada saat rencana dibuat (T hani, 2009:77-78).

\section{b. Tahap dasar perencanaan}

Semua kegiatan perencanaan pada dasarnya melalui empat tahap berikut ini: ( $T$ hani, 2009: 79)

1). Menetapkan tujuan atau serangkaian tujuan. Perencanaan dimulai dengan keputusan-keputusan tentang keinginan atau kebutuhan organisasi atau kelompok kerja. tanpa rumusan tujuan yang jelas, organisasi akan menggunakan sumber daya-sumber daya secara tidak efektif

2). Merumuskan keadaan saat ini. Pemahaman akan posisi perusahaan sekarang dari tujuan yang hendak dicapai atau sumber daya-sumber daya yang tersedia untuk pencapaian tujuan adalah sangat penting. Karena tujuan dan rencana menyangkut waktu yang akan datang

3). Mengidentifikasikan segala kemudahan dan hambatan. Segala kemudahan dan hambatan perlu diidentifikasikan untuk mengukur kemampuan organisasi dalam mencapai tujuan. Walaupun sulit dilakukan antisipasi keadaan, masalah dan kesempatan serta ancaman yang meungkin terjadi di waktu mendatang adalah bagian esensi dari proses perencanaan.

4). Mengembangkan rencana atau serangkaian kegiatan untuk pencapaian tujuan. Tahap terakhir dalam proses perencanaan meliputi pengembangan berbagai alternative kegiatan untuk pencapaian tujuan, penilaian alternative-alterantif tersebut dan pemilihan alternative terbaik.

\section{c. Pengertian perencanaan keuangan}

Perencanaan keuangan adalah suatu ilmu yang menempatkan kajian tentang keuangan dengan menempatkan berbagai atribut keuangan secara terkonsep dan sistematis dengan menempatkan berbagai atribut keuangan secara jangka pendek dan panjang. Dalam konsep jangka pendek biasanya 1 tahun atau 12 bulan saja. Sedangkan jangka panjang beberapa pakar keuangan menyebutnya 2 hingga 5 tahun. Periode jangka panjang disebut carkawala perencanaan (planning horizon)( Fahmi, 2014: 7). 


\section{METODE}

Populasi dalam penelitian ini adalah mayarakat kota mataram. Sampel dalam penelitian ini diambil dari sebagian populasi yang ada. Teknik dalam pengambilan sampel adalah mengunakan teknik pengambilan random sampling dikarenakan untuk efesiensi penelitian. Untuk mendapatkan sampel yang representative dapat dilakukan dengan dua cara yaitu mengambil sampel dari populasi tanpa memperhitungkan jumlah populasi dan mengambil sampel dari populasi dengan mempertimbangkan besar kecilnya populasi. Adapun jumlah sampel yang akan diambil dalam penelitian ini sebanyak 100 orang.

Alat ukur penelitian ini berbentuk angket/kuisioner. Kuisioner yang digunakan adalah kuisioner tertutup yang memberikan kepada responden untuk memilih satu atau lebih kemungkinan-kemungkinan jawaban yang telah disediakan. Skala yang digunakan untuk mengukur adalah Skala Likert. Alternatif jawaban diberi skor dari nilai 1 sampai 5.

\section{ANALISIS DATA}

\section{Analisis Regresi Sederhana}

Uji regresi digunakan untuk meramalkan suatu variabel dependen(y) dan variabel independent $(x)$ dalam suatu persamaan linier.

Formula persamaan linier:

$Y=a+b X$

Dimana :

$\mathrm{Y}=$ Variabel Dependent (Perencanaan Keuangan)

$X=$ Variabel Independent(Literasi Keuangan)

$\mathrm{a}=$ konstanta

$b=$ koefisien regresi (kemiringan); besaran Response yang ditimbulkan oleh Predictor.

Pengujian hipotesis dilakukan untuk mengetahui hasil uji hipotesis menggunakan Uji F dan Uji T, Sedangkan Uji keabsahan data dalam penelitian kuantitatif terdiri meliputi: Uji asumsi klasik meliputi uji normalitas dan uji linearitas. Setiap instrument penelitian harus diuji, sebab uji Instrumen bertujuan untuk mengetahui setiap pertanyaan yang digunakan disebut valid (tepat) dan reliable (stabil), maka dilakukan analisis validitas dan analisis reliabilitas terhadap kuesioner (Ghozali,2006:45-49). 


\section{HASIL DAN PEMBAHASAN}

\section{Analisis Regresi Sederhana}

Untuk mengetahui nilai koefisien regresi dalam penelitian ini maka dapat dilihat dari output SPSS sebagai berikut:

Tabel 1 Coefficients

\begin{tabular}{|c|c|c|c|c|c|c|}
\hline & \multirow{3}{*}{ Model } & \multicolumn{5}{|c|}{ Standardized } \\
\hline & & \multicolumn{2}{|c|}{ Unstandardized Coefficients } & $\begin{array}{l}\text { Coeffi- } \\
\text { cients }\end{array}$ & $\mathrm{T}$ & Sig. \\
\hline & & B & Std. Error & Beta & & \\
\hline \multirow[t]{2}{*}{1} & (Constant) & 66.471 & 7.129 & & 9.324 & .000 \\
\hline & Literasi Keuangan & .194 & .091 & .210 & 2.125 & .036 \\
\hline
\end{tabular}

a. Dependent Variable: Perencanaan Keuangan Keluarga

1). merupakan angka konstan dari unstandardized coefficient yang memiliki nilai sebesar 66,471. Nilai ini merupakan nilai konstan yang mempunyai arti bahwa jika tidak ada literasi keuangan maka nilai perencanaan keuangan keluarga sebesar 0,194.

2). merupakan koefisien regresi dan nilainya sebesar 0,94. Angka ini mengandung arti bahwa setiap penambahan $1 \%$ literasi keuangan (X) maka perencanaan keuangan keluarga (Y) akan meningkat sebesar 0,194.

Nilai koefisien regresi bernilai positif $(+)$ artinya dapat dikatakan bahwa literasi keuangan $(X)$ berpengaruh positif terhadap perencanaan keuangan keluarga $(Y)$. sehingga persamaan regresinya adalah $\mathrm{Y}=66,741+0,194 \mathrm{X}$

\section{Uji koefisien determinasi}

Koefisien determinasi $\left(R^{2}\right)$ pada intinya mengukur seberapa jauh kemampuan model dalam menerangkan variasi variabel dependen. Nilai koefisien determinasi adalah antara nol dan satu. Nilai $\mathrm{R}^{2}$ yang kecil berarti kemampuan variabel-variabel independent dalam menjelaskan variasi variabel dependen amat terbatas.

Untuk mengetahui nilai koefisien determinasi dalam penelitian ini maka dapat dilihat dari output SPSS sebagai berikut:

Tabel 2 :Model Summary

\begin{tabular}{llrrr}
\hline Model & R & R Square & Adjusted R Square & Std. Error of the Estimate \\
\hline 1 & $.210^{\mathrm{a}}$ & .044 & .034 & 5.786 \\
\hline
\end{tabular}

a. Predictors: (Constant), Literasi Keuangan

Bedasarkan tampilan output SPSS model summary besarnya nilai korelasi/ hubungan $\mathrm{R}$ yaitu sebesar 0,210. Dari output tersebut diperoleh koefisien determina- 
si (R Square) sebesar 0,044 yang mengandung pengertian bahwa pengaruh variabel bebas (literasi keuangan) memiliki pengaruh kontribusi sebesar 4,4\% terhadap variabel terikat (perencanaan keuangan keluarga) dan 95,6 dipengaruhi oleh faktor-faktor lain diluar variabel $X$.

\section{Uji Hipotesis}

Untuk pengujian hipotesis dalam penelitian ini adalah menggunakan pengujian data secara statistik dimana tujuannya untuk mengetahui apakah hipotesis yang diajukan diterima atau ditolak.Untuk menguji hipotesis dalam penelitian ini adalah dengan menggunakan:

1. Uji Pengaruh Simultan (F Test)

Uji statistik F pada dasarnyamenunjukkan apakah semua variabel independent atau bebas yang dimasukkan dalam model mempunyai pengaruh secara Bersama-sama terhadap variabel dependen/terikat. Hioptesis nol (Ho) yang hendak diuji adalah apakah semua parameter dalam model sama dengan nol.Dasar pengambilan keputusan dari uji $\mathrm{F}$ adalah sebagai berikut:

a) Jika nilai signifikansi<0,05 artinya variabel $x$ berpengaruh terhadap variabel y

b) Jika nilai signifikansi>0,05 artinya variabel $x$ tidak berpengaruh terhadap variabel y

Untuk menguji nilai F dalam penelitian ini maka dapat dilihat dari output SPSS sebagai berikut:

Tabel 3:

Uji Nilai $F$

\begin{tabular}{ccccccc}
\hline No & Regresi & Sum of Squares & df & Mean Square & F & Sig. \\
\hline 1 & Regression & 151.199 & 1 & 151.199 & 4.516 & $.036^{\mathrm{a}}$ \\
2 & Residual & 3281.311 & 98 & 33.483 & & \\
& Total & 3432.510 & 99 & & & \\
\hline
\end{tabular}

a. Predictors: (Constant), Literasi Keuangan

b. Dependent Variable: Perencanaan Keuangan Keluarga

Bedasarkan output tersebut dapat diketahui bahwa nilai $F$ hitung sebesar 4,516 dengan tingkat signifikansi sebesar 0,036 <0,05maka model regresi dapat dipakai untuk memprediksi variabel partisipasi atau dengan kata lain ada pengaruh variabel literasi keuangan $(\mathrm{X})$ terhadap variabel perencanaan keuangan keluarga $(\mathrm{Y})$ 


\section{Uji T}

Untuk mengkaji apakah hipotesis yang dilakukan diterima atau ditolak, dilakukan uji signifikan yaitu dengan mengkonsultasikan nilai t hitung dengan nilai Ttabel pada tingkat kepercayaan95\% ( $\alpha=0,05)$ sehingga digunakan taraf signifikansi 5\% untuk hipotesis teoritis harus dijadikan sebagai hipotesis kerja.Dasar pengambilan keputusan dari uji F adalah sebagai berikut:

b. Jika nilai $t$ hitung $>t$ tabel, artinya variabel $x$ berpengaruh terhadap variabel y

c. Jika nilai $t$ hitung $<\mathrm{t}$ tabel artinya variabel $\mathrm{x}$ tidak berpengaruh terhadap variabel y

Untuk mengetahui hipotesis diterima atau ditolak dalam penelitian ini maka dapat dilihat dari output SPSS sebagai berikut:

Tabel 4:

Tabel Uji T

\begin{tabular}{|c|c|c|c|c|c|c|}
\hline & \multirow[t]{2}{*}{ Model } & \multicolumn{2}{|c|}{$\begin{array}{r}\text { Unstandardized } \\
\text { Coefficients }\end{array}$} & \multirow{2}{*}{$\begin{array}{c}\text { Standardized Coeffi- } \\
\text { cients } \\
\text { Beta } \\
\end{array}$} & \multirow[t]{2}{*}{$\mathrm{T}$} & \multirow[t]{2}{*}{ Sig. } \\
\hline & & $\mathrm{B}$ & Std. Error & & & \\
\hline \multirow[t]{2}{*}{1} & (Constant) & 66.471 & 7.129 & & 9.324 & .000 \\
\hline & Literasi Keuangan & .194 & .091 & .210 & 2.125 & .036 \\
\hline
\end{tabular}

Bedasarkan output diatas dapat diketahui bahwa nilai t hitung sebesar 2,125. Karena nilai t hitung sudah ada, maka langkah selanjutnya adalah menghitung t tabel dengan rumus: nilai $a / 2=0,05 / 2=0,025$. Sedangkan derajat kebebasan (df) $=n-2=100-$ $2=98$. Setelah itu dilihat pada $t$ tabel maka didapat nilai $t$ tabel sebesar 1,980. Hal ini berarti nilai t hitung 2,125 > t tabel 1,980, sehingga dapat disimpulkan bahwa Ho ditolakdan Ha diterima yang berarti bahwa "ada pengaruh literasi keuangan $(X)$ terhadap perencanaan keuangan keluarga $(\mathrm{Y})$

\section{SIMPULAN}

Bedasarkan analisis data dan beserta interpretasinya, maka hasil penelitian ini dapat disimpulkan bahwa literasi keuangan $(X)$ berpengaruh positif terhadap perencanaan keuangan keluarga $(Y)$ di kota Mataram sesuai dengan analisis yang digunakan yaitu analisis regresi sederhana dengan persamaan regresinya adalah $\mathrm{Y}=66,741+0,194 \mathrm{X}$. Nilai merupakan angka konstan dari unstandardized coefficient yang memiliki nilai sebesar 66,471 . Nilai ini merupakan nilai konstan yang mempunyai arti bahwa jika tidak ada literasi keuangan maka nilai perencanaan keuangan keluarga sebesar 0,194. Sedangkan bmerupakan koefisien regresi dan nilainya sebesar 0,94. 
Angka ini mengandung arti bahwa setiap penambahan $1 \%$ literasi keuangan (X) maka perencanaan keuangan keluarga (Y) akan meningkat sebesar 0,194.

Kemudian membuktikan ho diterima atau ditolah dilakukan 2 pengujian hipotesis baik Uji F dan Uji T. Hasil output dari uji F diketahui bahwa nilai F hitung sebesar 4,516 dengan tingkat signifikansi sebesar 0,036. Tingkat signifikansi 0,036<0,05 maka dapat diinterpretasikan bahwa ada pengaruh variabel literasi keuangan $(X)$ terhadap variabel perencanaan keuangan keluarga $(Y)$.

Demikian pula dibuktikan dengan pengujian hipotesis yang kedua dengan uji T. Hasil output dari uji T dapat diketahui bahwa nilai t hitung sebesar 2,125. Kemudian setelah t hitung dibandingkan dengan t tabel yang memiliki nilai sebesar 1,980. Dengan nilai t hitung 2,125 > t tabel 1,980dapat disimpulkan bahwa Ho diterima yang berarti bahwa "ada pengaruh literasi keuangan $(\mathrm{X})$ terhadap perencanaan keuangan keluarga $(\mathrm{Y})$ "

\section{PUSTAKA ACUAN}

Arikunto, Suharsimi. (1997) Prosedur Penelitian Suatu Pendekatan Praktek Jakarta: Penerbit Rineka Cipta

Darmawan, Deni. (2013). Metode Penelitian Kuantitatif. Bandung: PT Remaja Rosdakarya

Fahmi, Irham. (2014). Pengantar Manajemen Keuangan. Bandung: Cv Alfabeta

Ghozali, Imam. (2006).Aplikasi Multivariate dengan Program SPSS (Semarang: Badan Penerbit Universitas Diponegoro

Handoko, T Hani.(2009). Pengantar Manajemen. Yogyakarta: BPFE

Kuswanto, Dedy. (2012). Statistik untuk pemula dan orang awam. Jakarta: Laskar Askara

Mulya Astuti, Alfira. (2016) .Statistika Penelitian. Mataram:Insan Madani Publishing Otoritas Jasa Keuangan. (2016) Perencanaan Keuangan. Jakarta: OJK

Otoritas Jasa Keuangan. (2016). Literasi, edukasi, dan Inklusi Keuangan. Jakarta: Direktorat Literasi dan Edukasi

Soehartono, Irawan. (1995).Metode Penelitian Sosial, Bandung: Penerbit Rosda Karya

Sugiyono. (2004)Penelitian Bisnis. Bandung: Alfabeta

Siregar, Syofian. (2007) Statistika Deskriptifuntuk Penelitian. Jakarta: PT Raja Grafindo Persada

Toto Syatori Nasehudin dan Nanang Gozali.(2012). Bandung: Penerbit Pustaka Setia 